\title{
SOSIALISASI MASYARAKAT EKONOMI ASEAN: PELUANG DAN TANTANGAN BAGI INDONESIA
}

\author{
Ignatius Ismanto \\ Fakultas Ilmu Sosial dan Ilmu Politik \\ Universitas Pelita Harapan, Karawaci - Tangerang \\ ignatius.ismanto@uph.edu
}

\begin{abstract}
Abstrak
Integrasi ekonomi kawasan sesungguhnya merupakan ide atau gagasan yang relatif baru bagi ASEAN. Pembentukan MEA (Masyarakat Ekonomi ASEAN) yang dicanangkan ASEAN pada 2015 merupakan gagasan yang dimaksudkan untuk mendorong integrasi ekonomi negara-negara ASEAN. MEA merupakan bentuk regionalisme baru (New Regionalism). Pembentukan MEA dipandang sebagai strategi kolektif yang dibangun oleh negara-negara di kawasan Asia Tenggara dalam menyikapi perubahan ekonomi global yang tidak menentu. MEA menjadi instrumen ekonomi yang menarik, khususnya dalam mendukung agenda politik ASEAN yaitu mewujudkan stabilitas keamanan kawasan. MEA akan menfasilitasi kerjasama ASEAN untuk mendorong proses integrasi ekonomi kawasan. Proses integrasi ekonomi ASEAN ini mendorong tantangan perubahan yang luas bagi negara-negara ASEAN, termasuk Indonesia. Kegiatan Pengabdian kepada Masyarakat (PkM) ini dimaksudkan untuk mensosialisasikan gagasan pembentukan MEA serta tantangan yang dihadapi Indonesia dalam menyikapi pelaksanaan MEA. Kegiatan PkM ini juga dimaksudkan untuk menumbuhkan kesadaran masyarakat terhadap tantangan dari perubahan ekonomi global. Metode yang digunakan dalam sosialisasi dilakukan melalui penyelenggaraan seminar dan diskusi. Untuk melihat efektivitas sosialisasi, yaitu pengenalan dan pemahaman terhadap gagasan pembentukan MEA itu dilengkapi dengan penyampaian quiz. Kegiatan PkM ini diselenggarakan di lingkungan Gereja Protestan Indonesia bagian Barat (GPIB) Jemaat Karunia, Ciputat, Tangerang Selatan. Kegiatan sosialisasi dalam memperkenalkan gagasan pembentukan MEA serta tantangan yang dihadapi oleh Indonesia ini memperoleh sambutan yang luas dari kalangan pengurus gereja.
\end{abstract}

Kata Kunci: Regionalisme, Integrasi Ekonomi, ASEAN

\section{PENDAHULUAN}

\section{Latar Belakang}

Masyarakat Indonesia sangat terbiasa mendengar kosa kata 'MEA' yang merupakan singkatan dari Masyarakat Ekonomi ASEAN. Namun, mereka umumnya kurang memberikan perhatian terhadap gagasan dan konsekuensi terhadap pembentukan Masyarakat Ekonomi ASEAN (MEA). MEA merupakan kesepakatan regional yang telah dirumuskan oleh negaranegara ASEAN pada 2016. MEA dapat dipandang sebagai gagasan besar yaitu untuk mendorong integrasi ekonomi kawasan, dan karena itu dapat membawa implikasi sosial yang luas bagi masyarakat ASEAN, termasuk Indonesia. MEA merupakan bentuk regionalisme yang penting di kawasan Asia Tenggara. MEA menjadi strategi kolektif ASEAN dalam menyikapi perubahan ekonomipolitik global. Perubahan ekonomi-politik global yang dewasa ini tidak lagi dicirikan oleh persaingan ideologi tetapi oleh persaingan ekonomi. Kepentingan ASEAN dalam pembentukan MEA tentu tidaklah berlangsung dalam ruang politik yang hampa. Kawasan Asia

\begin{tabular}{l|l} 
& Ekonomi, Sosial, dan Budaya \\
1067
\end{tabular} 
Tenggara merupakan arena persaingan kepentingan negara-negara besar. MEA merupakan forum kerjasama ekonomi regional yang sarat dengan muatan dimensi politik. MEA menjadi instrumen ekonomi yang digunakan ASEAN dalam mendukung agenda politik ASEAN dalam mempertahan stablitas kawasan di tengah perubahan ekonomi-politik global itu.

\section{Tujuan}

MEA memerlukan dukungan keterlibatan aktor yang luas, tidak hanya negara tetapi juga aktor-aktor non-negara, seperti: perguruan tinggi, gereja, NGO, kalangan usaha dan lain-lain.Sehubungan dengan itu paper yang telah dipresentasikan dalam seminar pada hari Sabtu, 29 Juni 2019 bagi Jemaat Karunia, Gereja Protestan Indonesia bagian Barat (GPIB), Ciputat - Tangerang Selatan ini dimaksudkan untuk memperkenalkan gagasan pembentukan MEA, serta menumbuhkan kesadaran masyarakat terhadap tantangan di tengah perubahan ekonomi global dewasa ini.

\section{Tinjauan Pustaka}

Kegiatan PkM ini dimaksudkan untuk memperkenalkan gagasan ASEAN dalam pembentukan regionalisme Masyarakat Ekonomi ASEAN (MEA), serta menumbuhkan kesadaran bagi masyarakat terhadap tantangan yang dihadapi masyarakat Indonesia seiring dengan perubahan ekonomi regional dan global. Sehubungan ini, kajian kepustakaan dikembangkan untuk membangun kerangka konspetual dalam menjelaskan gagasan pembentukan MEA

\section{Regionalisme Baru}

ASEAN merupakan bentuk regionalisme di kawasan Asia Tenggara. Ada sejumlah isu yang menarik dari pernyataan itu, yaitu: apa yang dimaksudkan dengan regionalisme? Mengapa Asia Tenggara merupakan isu yang menarik. Regionalisme berasal dari kata 'region' yang sering diartikan kawasan. Dalam studi Hubungan Internasional, region atau kawasan sering diartikan sebagai kumpulan negara-negara yang secara geografis berdekatan (Snyder, 2008). Namun, mendefinisikan region yang hanya mendasarkan aspek kedekatan geografis (geographic proximity) semata-mata, sering dianggap menimbulkan masalah baru, yaitu dari mana kedekatan geografis itu dimulai dan sampai dimana kedekatan geografis itu berakhir. Hettne dan Soderbaun (2002) memasukkan aspek-aspek lainnya, disamping kedekatan geografis), seperti: kesamaan budaya, keterikatan sosial dan sejarah yang sama - dalam memahami pengertian region atau kawasan. Regionalisme, karena itu, dapat diartikan sebagai upaya dari kumpulan negaranegara yang secara geografis berdekatan, memiliki aspek kesamaan budaya, agama, bahasa, etnis atau kesamaan latar belakang sejarah yang sama dalam mewujudkan kepentingan mereka bersama.

Dalam studi Hubungan Internasional, regionalisme bukanlah fenomena yang baru. Regionalisme sering dibedakan antara regionalisme lama (old regionalism) dan regionalisme baru (new regionalism). Apa yang membedakan old regionalism dan new regionalism?. Pembentukan old regionalism umumnya banyak dipicu oleh persaingan ideologi. Old Regionalism ini umumnya berkembang subur pada 1960-1970 yaitu saat berlangsung Perang Dingin. Sedangkan pembentukan new regionalism ini umumnyalebih dipicu oleh persaingan ekonomi. New regionalism berkembang subur setelah tahun 1980-an, yaitu sejak Perang Dingin berakhir.

\section{Integrasi Ekonomi Kawasan}

Cohn (2010) dalam bukunya Global Political Economy menjelaskan proses integrasi ekonomi suatu kawasan. Ada 5 (lima) tahapan yang dilalui dalam mendorong integrasi ekonomi kawasan itu. Pertama yaitu pembentukan Free Trade Area (FTA). Kedua yaitu pembentukan Custom Union (CU). Ketiga yaitu pembentukan Common Market atau Pasar Bersama. Ke-empat yaitu 
pembentukan Economic Union dan Kelima yaitu pembentukan Political Union.

Pembentukan FTA merupakan tahapan integrasi ekonomi kawasan yang paling dangkal. Pada tahapan ini, negara-negara yang menjalan kesepakatan untuk membentuk FTA membangun komitmen untuk menurunkan tarif terhadap sejumlah komoditi dan atau penghapusan terhadap hambatan non-tarif. Penurunan tarif itu hanya berlaku bagi negaranegara yang membangun kesepakatan dalam membentuk FTA. Negara yang bukan anggota dalam FTA tidak dapat memanfaatkan penurunan tarif itu. Sehubungan dengan itu, pembentukan FTA ini sering dianggap diskriminatif. Pembentukan FTA, karena itu, cenderung mendorong pembentukan FTA yang lain. Apa yang diharapkan dari pembentukan FTA ini? Pembentukan FTA itu dimaksudkan untuk mendorong peningkatan perdagangan antar negara anggota.

Pembentukan Custom Union (CU) merupakan tahapan integrasi ekonomi kawasan yang lebih dalam dari pembentukan FTA. Pada tahapan $\mathrm{CU}$ ini, negara-negara yang menjadi anggota tidak hanya sepakat untuk menurunkan tarif, tetapi juga mulai memberlakukan penyeragaman proses bea cukai. Proses ini tidak hanya berlaku bagi negara anggota, tetapi juga diberklakukan bagi negara yang bukan anggota.

Tahapan integrasi ekonomi yang lebih dalam dari pembentukan FTA dan pembentukan CU yaitu pembentukan Common Market (CM) atau disebut Pasar Bersama. Pembentukan CU tidak hanya dimaksudkan untuk mendorong arus kelancaran barang dan jasa, tetapi juga membuka peluang bagi peningkatan arus investasi serta mobilitas tenaga kerja di antara negara anggota. Pada tahapan Pasar Bersama ini, negara-negara tidak hanya sepakat untuk menurunkan tarif, memberlakukan prosedur bea cukai, tetapi mereka mulai mensinkronisasikan kebijakankebijakan sosial-ekonomi lainnya dalam mendukung kelancaran arus investasi serta mobilitas tenaga kerja, seperti: sinkronisasi terhadap sistem pengupahan, sistem jaminansosial, dan sebagainya.

Tahapan integrasi kawasan yang lebih dalam dari CM yaitu Economic Union (EU).
Dalam EU ini negara-negara yang menjalin kesepakatan regional menyamakan kebijakan moneter mereka, bahkan mungkin dapat menerapkan penggunaan mata uang yang sama.

Tahapan integrasi ekonomi kawasan yang paling dalam adalah pembentukan Political Union.Pembentukan political union memungkinkan negara-negara yang menjadi anggota menyerahkan kewenangan tertentu dalam urusan perdagangan kepada lembaga supra-nasional.

\section{METODE}

Penyelenggaraan seminar dan diskusi yang telah dirancang dalam kegiatan PkM dengan tema "Perubahan Ekonomi Global: Peluang dan Tantangan Tenaga Kerja Ekonomi ASEAN" merupakan metode yang dikembangkan untuk memperkenalkan gagasan pembentukan MEA. Jadi, seminar menjadi metode yang digunakan untuk sosialisasi gagasan MEA. Mengapa seminar dan diskusi dipilih sebagai metode dalam mensosialisasikan gagasan pembentukan MEA? Bagaimana seminar dan diskusi ini diselenggarakan dalam mendukung sosialisasi. Seminar dan diskusi dirancang untuk mendorong keterlibatan aktif peserta dalam penyampaian dan pemahaman ide atau gagasan. Kepesertaan dalam seminar ini, karenanya, menjadi pertimbangan yang penting. Para peserta yang diundang, terutama mereka yang menjadi pengurus suatu organisisasi atau kalangan aktivis. Mengapa pengurus atau aktivia?. Diharapkan mereka ini-pula yang akan menyebar-luaskan ide-ide atau gagasan pada forum-forum lain, yaitu forum dimana mereka aktif selama ini. Demikian pula, seminar dan diskusi menjadi forum yang lebih inter-aktif dalam memahami ide atau gagasan baru. Seluruh materi seminar juga diberikan dalam bentuk USB, dimana seluruh peserta mendapatkan meteri itu. Untuk melihat efektivitas pengenalan gagasan pembentukan MEA, kegiatan seminar dalam PkM ini mengembangkan sistem penilaian bagi peserta seminar. Sistem penilaian ini memberikan sejumlah pertanyaan (Quiz) dari materi yang telah dipresentasikan dalam seminar. Bagi 
peserta yang dapat menjawab pertanyaan dengan benar diberikan insentif, yaitu berupa souvenir dari UPH. Penyelenggaraan Quiz ini diumumkan sebelum seminar dimulai dan dimaksudkan agar peserta memberikan perhatian yang lebih serius terhadap materi yang disampaikan.

\section{HASIL PEMBAHASAN}

Seminar yang hanya berlangsung selama 1 (satu) jam menggaris-bawahi sejumlah gagasan yang penting tentang alasan, motivasi atau kepentingan ASEAN dalam mendorong proses integrasi ekonomi kawasan serta tantangan yang dihadapi Indonesia. Seminar ini bertolak dari dasar pemikiran bahwa MEA merupakan 'state-project', yaitu komitmen yang dibangun oleh negara-negara anggota ASEAN. Kominten yang dibangun oleh kesepuluh negara ASEAN itu tidak-lah berlangsung dalam ruang politik yang hampa. Apa yang mendorong mereka membangun komitmen itu? Pembentukan MEA sangat dilatar belakangi oleh perubahan ekonomi global yang semakin tidak menentu. Perubahan ekonomi global yang semakin ditandai oleh menajamnya persaingan kepentingan ekonomi negara-negara besar di kawasan Asia. ASEAN sejak terbentuknya pada 1967 pada hakekatnya berkeinginan untuk mencegah dominasi dari persaingan kepetingan negara-negara besar di kawasan Asia. MEA diharapkan menjadi strategi kolektif bagi ASEAN dalam menyikapi perubahan ekonomi global itu, mencegah dominasi negara-negara besar. ASEAN yang secara ekonomi kuat, yaitu ASEAN yang lebih dalam terintegrasi secara ekonomi akan meningkatkan bargaining power dalam membangun collecive action.

\section{a. Institutional Defisit}

Ravenhill dalam Avila (2001, hal. 20) menggunakan istilah 'institutional defisit' dalam menggambarkan minimnya kehadiran institusi regional di kawasan Asia. Apa yang dimaksud dengan institutional defisit? Konsep itu menggambarkan terbatasnya kehadirian institusi regional yang menfasilitasi kerjasama antar pemerintah (inter-governmental collaboration) di kawasan itu. Atau-pun jika ada, umumya kelangsungan institusi regional itu tidak berlangsung lama. Mengapa institusi regional yang menfasilitasi kerjasama antar negara di kawasan itu demikian langka? Salah satu alasan mengapa kawasan Asia, termasuk Asia Tenggara sangat minim terhadap keberadaan institusi regional adalah akibat dari latar belakang konflik yang berkepanjangan. Kawasan Asia Tenggara merupakan arena atau ajang persaingan kepentingan negara-negara besar. Dimasa lalu, India dan China bersaing untuk memperebutkan pengaruh di kawasan itu. Demikian pula, selama masa Perang Dingin, kawasan Asia Tenggara juga menjadi arena perebutan pengaruh negara-negara besar yang saling bersaing. Pembentukan ASEAN merupakan momentum yang penting bagi negara-negara kawasan Asia Tenggara untuk menfasilitasi kerjasama di antara mereka. ASEAN merupakan bentuk regionalism yang berperan penting bagi terwujudnya stabilitas kawasan selama ini. Kiranya penting untuk dicatat bahwa salah satu karakteristik tentang pembangunan regionalisme di kawasan Asia Tenggara, yaitu bahwa "national interests remain at the core of Asian regionalism"(Villa, 2001, hal. 22). Bagaimana kepentingan nasional itu diwujudkan? Sehubungan dengan itu, kepentingan nasional ini diwujudkan dengan mempertahankan gagasan kedaulatan negara. Konsep mempertahankan kedaulatan negara itu ditempuh dengan mengembangkan prinsip non-intervensi dalam ASEAN. Bahkan, prinsip non-intervensi menjadi norma yang dibangun oleh ASEAN, tidak hanya dalam menjalin kerjasama internal, yaitu dengan sesama negara anggota ASEAN, tetapi juga dalam menjalan kerjasama eksternal, yaitu dengan negara yang bukan menjadi negara ASEAN.Prinsip non intervensi ini mernjadi salah satu karakteristik prinsip-prinsip regional yang dibangun ASEAN yaitu melalui apa yang dikenal dengan ASEAN Way. McGillivray dan Carpenter (eds) (2013, hal. 4) dalam buku Narrowing the Development Gap in ASEAN menjelaskan bahwa "ASEAN Way is a sociocultural norm that emphasizes informal 
interaction, minimal institution development and peacefull settlement of dispute. Is is also characterized by non-intervention and desecion-making of consences". Seiring dengan perubahan ekonomi global, serta komitmen negara-negara ASEAN dalam memperdalam integrasi ekonomi mereka, bagaimana ASEAN menterjemahkan konsep non-intervensi dalam lingkungan ekonomi-politik global yang telah berubah -merupakan isu yang menarik. Mungkinkah prinsip non-intervensi itu akan diterjemahkan secara ketat seiring dengan semakin dalamnya integrasi ekonomi ASEAN?

\section{b. Integrasi Ekonomi: Gagasan yang relatif Baru}

Gagasan atau ide mempromosikan integrasi ekonomi kawasan bagi ASEAN sesungguhnya merupakan gagasan yang relatif baru. Sejak awal pendirian ASEAN kalangan pemimpin ASEAN tidak pernah berkeinginan untuk mendorong proses integrasi ekonomi kawasan, sekalipun-pun ASEAN merupakan forum kerjasama ekonomi. Gagasan untuk mendorong integrasi ekonomi kawasan itu mulai berkembang sejak berakhirnya Perang Dingin. Gagasan untuk mendorong proses integrasi ekonomi kawasan itu semula dirintis dengan pencanangan Pembentuan ASEAN Free Trade Area atau yang disingkat AFTA pada 1992. Upaya untuk semakin memperdalam integrasi ekonomi ASEAN ditempuh dengan pembentukan Masyarakat Ekonomi ASEAN (MEA). Pembentukan MEA ini sesungguhnya merupakan tahapan pembentukan Common Market. Pembentukan MEA yang dicanangkan pada 2015 dan mulai dilaksanakan pada 2016 dimaksudkan tidak hanya untuk memperlancar arus barang dan jasa di antara anggota ASEAN, tetapi juga membuka peluang arus migrasi tenaga kerja, khususnya kalangan tenaga kerja terdidik di antara anggota ASEAN.

Mengapa kalangan pemimpin ASEAN mulai bersedia untuk mempromosikan integrasi ekonomi kawasan setelah Perang Dingin berakhir?. Pergeseran itu sesungguh mencerminkan strategi ASEAN dalam menyikapi perubahan ekonomi-politik global. ASEAN merupakan manifestasi regionalisme yang selalu ditantang untuk menyikapi perubahan ekonomi-politik yang berkembang. Pada awal pendirian ASEAN pada 1967 yaitu semasa Perang Dingin, persaingan ideologi merupakan faktor yang mendorong pembentukan regionalisme. Selama masa Perang Dingin itu pula, ASEAN tidak berkepentingan untuk mendorong integrasi ekonomi di antara anggotanya. Namun perubahan ekonomi-politik global sejak Perang Dingin berakhir, persaingan ideologi -pun semakin melemah. Perubahan ekonomi-politik global semakin dicirikan oleh menguatnya persaingan ekonomi. Berakhirnya Perang Dingin telah membawa sejumlah implikasi yang menarik bagi ASEAN. Pertama, persaingan ideologi, yaitu antara: SosialismeKomunisme dan Liberalisme-Kapitalisme tidak lagi relevan bagi ASEAN. Itulah yang mendorong keanggotaan ASEAN semakin bertambah, dari yang semula lima anggota menjadi sepuluh anggota. Kelima negara anggota pendiri ASEAN semula merupakan negara-negara yang berhaluan anti Komunisme. Sedang kelima negara yang menjadi anggota baru ASEAN setelah Perang Dingin berakhir itu merupakan negara-negara yang menjalin aliansi dengan kekuatan Komunisme. Kedua, sejak Perang Dingin berakhir, persiangan ideologi itu bergeser menjadi persaingan ekonomi seiring dengan perubahan ekonomi global yang tidak menentu. Alasan itu-lah yang mendorong ASEAN mulai mempromosikan integrasi ekonomi kawasan.

Pembentukan MEA merupakan respon ASEAN dalam menyikapi perubahan ekonomipolitik global. Namun, satu hal yang penting untuk dicatat bahwa walau-pun ASEAN merupakan forum kerjasama ekonomi regional, bahkan akhir-akhir ini semakin aktif dalam mempromosikan integrasi ekonomi kawasan yang melibatkan keanggotaan negara-negara besar - alasan utama pembentukan ASEAN sesungguhnya adalah bersifat politik, yaitu mewujudkan stabilitas kawasan. Sehubungan dengan itu, pembentukan MEA dalam argumentasi ini dapat dipandang sebagai instrumen ekonomi dalam mendukung agenda politik ASEAN, yaitu mempertahan kawasan Asia Tenggara yang stabil dan makmur. 


\section{c. MEA: Pembentukan Pasar Bersama bagi ASEAN}

Pembentukan Masyarakat Ekonomi ASEAN merupakan tahapan pembentukan Common Market. Integrasi ekonomi ASEAN telah dirintis sejak pembentukan AFTA (ASEAN Free Trade Area ). MEA merupakan tahapan integrasi ekonomi yang lebih dalam dibandingkan AFTA. MEA juga akan membuka peluang migrasi tenaga kerja di antara negara-negara anggota ASEAN. Namun, hingga saat ini migrasi tenaga kerja itu masih tertutup untuk tenaga kerja yang tidak terampil (unskilled labor). Salah satu tantangan bagi ASEAN dalam mendorong proses integrasi itu adalah masih rendahnya intra-trade. Intra-trade yang rendah di kalangan ASEAN artinya perdagangan antar sesama negara ASEAN itu masih lebih rendah, yaitu hanya mencapai 23 persen. Bandingkan dengan Uni Eropa, misalnya, intra-trade di antara sesama negara anggota telah mencapai 70 persen. Rendahnya volume intra-trade ASEAN itu telah menjadi perhatian kalangan pemimpin ASEANdalam KTT ASEAN ke-34 di Bangkok pada Juni 2019 yang lalu. Sebagaimana dikemukan Perdana Menteri Malasia, Tun Dr Mahathir Mohamad (2019) bahwa: "many things emerged from the discussions with ASEAN leaders. Among the areas concerned is that trade within Asean is very small". Bagaimana mendorong peningkatan perdagangan merupakan isu yang sangat penting bagi ASEAN. Rendahnya volume perdagangan di antara negara-negara ASEAN itu telah menjadi isu bagi kalangan akademisi sejak 1990an. Ekonom Hadi Soesastro pernah mengemukakan bahwa "ASEAN is too big, but small". Artinya bahwa skala ekonomi ASEAN itu sangat lah besar, namun perdagangan di antara anggota ASEAN sangat rendah. Nampaknya intra-trade di kalangan ASEAN selama beberapa dasawarsa itu tidak mengalami kemajuan yang berarti. Padahal integrasi ekonomi kawasan merupakan elemen yang penting. ASEAN yang secara ekonomi semakin dalam terintegrasi secara ekonomi akan memberikan bargaining power yang lebih kuat bagi ASEAN dalam menghadapi persaingan kepentingan negara-negara besar di tengah perubahan ekonomi global yang tidak menentu dewasa ini.

\section{d. Migrasi dan Daya Saing Tenaga Kerja}

Salah satu tujuan yang menarik dalam pembentukan MEA yaitu menjadikan ASEAN sebagai kawasan ekonomi yang memiliki daya tarik bagi investasi global. Sekali-pun ASEAN diharapkan menjadi satu kesatuan ekonomi, namun dilihat dari karakteristik angkatan kerja - setiap anggota ASEAN memiliki keunggulan yang beragam. Keunggulan masing-masing negara itu-lah pula yang menentukan jenis investasi yang akan masuk ke setiap negara. Dilihat dari kualitas angkatan kerja, Indonesia memiliki kualitas angkatan kerja yang relatif rendah. Rendahnya kualitas angkatan kerja itu tercermin dari rendahnya tingkat pendidikan formal mereka, yaitu 60 persen angkatan kerja Indonesia masih berpendidikan Sekolah Dasar (SD) dan Sekolah Menengah Pertama (SMP). World Economic Forum mengembangkan Human Capital Index untuk mengukur daya saing ekonomi suatu negara. Human Capital Index itu dibangun berdasarkan 4 (empat) variabel, yaitu: (1) capacity berkaitan dengan literasi dan tingkat pendidikan, (2) deployment berkaitan dengan partisipasi tenaga kerja, pengguran, (3) development berkaitan dengan sistem pendidika, pelatihan kerja dan sekolah kejuruan, dan (4) know how berkaitan dengan penempatan tenaga kerja yang terdidik. Berdasarkan Human Capital Index itu, Indonesia menempati urutan yang ke-7. Urutan yang pertama adalah Singapura (Frendy Kurniawan, 2018). Artinya, Indonesia memiliki daya saing yang relatif rendah dibandingkan negara-negara ASEAN lainnya, terutama bila dilihat dari aspek ketenaga-kerjaan. Sehubungan itu, perbaikan kualitas angkatan kerja sangat-lah penting. PkM ini disamping memberikan pengetahuan tentang perbahan ekonomi kawasan juga membekali pengetahuan teknis, seiring dengan tuntutan kemajuan ekonomi, yaitu dalam memanfaatkan media komunikasi digital. 


\section{KESIMPULAN DAN SARAN}

Sosialisasi MEA kepada masyarakat luas merupakan proses yang panjang, yaitu dimulai dari dukungan kegiatan akademik. Kegiatan Pengabdian kepada Masyarakat (PkM) ini terinspirasi oleh kegiatan penelitian tentang Ekonomi-Politik Integrasi Ekonomi Asia Tenggara. PkM ini sesungguhnya merupakan sosialisasi terhadap sejumlah temuan hasil penelitian. Sehubungan dengan itu, ada sejumlah gagasan yang penting untuk digaris-bawahi:

Ekonomi global dewasa ini semakin dicirikan persaingan ekonomi kekuatan-kekuatan negara besar. Perubahan ekonomi-politik global itu telah mempengaruhi pembangunan regionalisme yang semula dipicu oleh persaingan ideologi menjadi persaingan ekonomi. Sekali lagi, perubahan ekonomipolitik global telah mempengaruhi pergeseran persaingan negara-negara besar, yaitu dari orientasi ideologi menjadi kekuatan ekonomi.

Pembentukan MEA pada hakekatnya merupakan strategi ASEAN dalam menyikapi perubahan ekonomi-politik global. MEA merupakan upaya kolektif yang ditempuh negara-negara ASEAN untuk memperdalam integrasi ekonomi mereka. Upaya kolektif itu diharapkan memperkuat bargaining ASEAN dalam menyikapi perubahan ekonomi global yang tidak menentu. Pembentukan ASEAN pada hakekatnya dimaksudkan untuk mencegah dominasi negara-negara besar di kawasan Asia Tenggara. Dengan demikian, MEA merupakan instrumen ekonomi dalam mendukung agenda politik ASEAN dalam mewujudkan stabilitas kawasan.

Intergasi ekonomi ASEAN akan membawa implikasi yang luas bagi negaranegara ASEAN, termasuk Indonesia. Integrasi ekonomi itu tidak saja mendorong meningkatnya arus barang, jasa dan investasi, tetapi juga semakin terbukanya arus migrasi tenaga kerja antar negara-negara ASEAN. Bagi Indonesia, terbukanya arus migrasi ini tidak saja menjadi peluang tetapi sekaligus dapat menjadi tantangan. Terbukanya migrasi tenaga kerja menjadi peluang, yaitu semakin luasnya kesempatan kerja. Namun, relatif rendahnya kualitas angkatan kerja dapat menjadi tantangan bagi Indonesia dalam memanfaatkan peluang itu. Rendahnya kualitas angkatan kerja itu dicirikan oleh relatif rendahnya tingkat pendidikan formal mereka, yaita rata-rata 40,5 persen tamatan Sekolah Dasar (BPS, 2019). Sehubungan dengan itu, peningkatan ketrampilan - merupakan salah satu aspek yang penting dalam meningkatkan kualitas angkatan kerja itu. Peningkatan kualitas angkatan kerja itu tidak saja menjadi tanggung jawab pemerintah, tetapi juga menuntut tanggung jawab seluruh elemen masyarakat, termasuk pergurunan tinggi dan masyarakat agama. PkM ini merupakan bagian dari mata rantai yang panjang itu.

\section{UCAPAN TERIMA KASIH}

Kegitan PkM yang diawali dengan seminar dengan tema: Perubahan Ekonomi Global: Peluang dan Tantangan bagi Indonesia diselenggarakan pada hari Sabtu, 29 Juni 2019, Jam 0830 - 1400. Kegiatan PkM ini merupakan kerjasama antara Gereja Protestan Indonesia Bagian Barat (GPIB) - Ciputat dan Fakultas Ilmu Sosial dan Ilmu Politik - Universitas Pelita Harapan, Karawaci-Tangerang. Kegiatan PkM ini diselenggarakan di Gedung GPIB - Jalan Asrama Polri No. 1 Ciputat, Tangerang Selatan, Banten 15411 dan diikuti oleh Jemaat Karunia serta sejumlah pengurus gereja yang tergabung dalam Persekutuan Gereja-Gereja di Indonesia Wilayah Banten Terselenggaranya kegiatan PkM dimungkinkan karena dukungan dan terlibatan berbagai pihak. Untuk itu, kami Tim penyelenggara $\mathrm{PkM}$ menyampaikan penghargaan dan terima kasih yang sebesarbesarnya kepada:

Pertama, Dr.-Ing Ihan Martoyo, S.T.MSc., selaku Ketua Lembaga Penelitian dan Pengabdian kepada Masyarakat (LPPM) Universitas Pelita Harapan yang telah menfasilitasi pendanaan kegiatan PkM ini. Juga kepada seluruh staf LPPP, yaitu: Dr. Rudi Pramono, Ibu Maya, Ibu Sriyana Busa dan Mas Sigit yang telah mendukung kelancaran 
administrasi kegiatan PkM hingga pelaporan kegiatan PkM

Kedua, Dr. Aleksius Jemadu, Ph.D, selaku Dekan Fakultas Ilmu Sosial dan Ilmu Politik, UPH yang telah memberikan dukungan moral dalam kegiatan sosialisasi hasil penelitian tentang ASEAN

Ketiga, Elfi,S.E., M.B.A., selaku Direktur Administrasi dan Keuangan, FISIP UPH yang telah membantu kelancaran pelaporan admininstrasi keuangan.

Keempat, Elizabeth B. Nasution, S.I.P., M.A., selaku Ketua Program Studi Hubungan Internasional yang telah memberi dukungan bagi kelancaran kegiatan PkM

Kelima, Pendeta Elkarya C. Telaumbanua, M. Th., MA selaku Ketua Persekutuan Gereja-Gereja di Indonesia Wilayah Banten yang telah memberikan dukungan serta keterlibatan dalam kegiatan PkM ini.

Keenam, Jemaat Karunia - Gereja Protestan Indonesia Bagian Barat (GPIB) yang telah berpartisipasi dan memberikan fasilitas bagi terselenggaranya kegiatan seminar

Ketujuah, Sejumlah kalangan mahasiswa FISIP-UPH yang terlibat sejak persiapan hingga pelaksanaan kegiatan PkM, yaitu: Janet Yenandra (00000023211); Devina Putri (00000028344); Erika Santi (00000022300); Fransiska Karmelia (00000021846) dan Lidya Dayana (00000019550)

Tim PkM FISIP -UPH

Ignatius Ismanto

Carly Stiana Sumampouw

Reggiannie Christy Natalia

\section{REFERENSI}

Avila, John Lawrence. "APEN and ASEM: Reconciling Two Regional Agenda" dalam Wilfrido V. Villacorta (2001). Coalition Building and APEC. Makati: PASCN.

Cohn, Theodore H.,(2010). Global Political Economy: Theory and Practice, New York: Person.

Snyder, Craig A.(2008). Contemporary Security and Strategy. Macmillan: Palgrave.

Hettne,B. and Soderbaun (2002). Theorizing the Rise of Regiones. London: Routledge.

Kurniawan, Frandi (2019). "Situasi Genting Angkatan Kerja Indonesia", diunggah dari https://tirto.id/situasi-genting-angkatankerja-indonesia-cFal, pada 28 Agustus 2019, Jam 12:32.

Mahatir, Mohammad, Malaymail, 23 Juni 201.

McGillivray, Mark dan David Carpenter (eds.,). (2013). Narrowing the Development Gap in ASEAN, London: Routledge. 